\title{
大阪南港野鳥園湿地のグリーンタイド制御に関する一考察
}

\section{A Method for Preventing the Outbreak of Green Tides at the Osaka Nanko Bird Sanctuary}

\author{
島並 諒 $^{1} \cdot$ 遠藤 徹 $^{2} \cdot$ 矢持 進 $^{3}$ \\ Ryo SHIMANAMI, Toru ENDO and Susumu YAMOCHI
}

\begin{abstract}
Field surveys and laboratory experiments were carried out to prevent the outbreak of green tides at the north pond of Osaka Nanko bird sanctuary. Dense blooms of green algae, Ulva pertusa, Ulva ohnoi and Rhizoclonium riparium were frequently observed in 2005-2012 and the most dominant species gradually changed from Ulva pertusa to Ulva ohnoi, which is partly due to temperature increase and low salinity at a growing season. Laboratory experiments revealed that photosynthesis was inhibited when they were exposed to air for 6 hours at $35^{\circ} \mathrm{C}$ followed by a low salinity of $20 \mathrm{psu}$. These results suggest the possibility of controlling green tides of Ulva pertusa and Ulva ohnoi by a combination of exposure to air with low salinity in summer
\end{abstract}

\section{1.はじめに}

近年，港湾整備等によって消失した浅場や干潟域を， 人工干潟の造成などによって回復させる事例が増加して いる. 一般的に干潟では海水中の栄養塩を微細藻類等が 吸収し，そこから食物連鎖によって鳥類が栄養物質を蓄 えることで, 海域から陸域へと系外除去される。この作 用により，富栄養化が深刻な海域の干潟では海水浄化が 期待されている. しかし富栄養海域に造成された閉鎖性 人工干潟では, 特定の大型藻類が異常繁茂する現象「グ リーンタイド」の発生が世界中で報告されている.グリ ーンタイドの原因となるアオサなどの緑藻類は他の海藻 に比べて生長が早く, 環境中で優占し易いため, 栄養塩 が豊かな海域で異常に繁茂する。繁茂した海藻は陸域に 打ち上げられると腐敗し, 景観悪化や悪臭を引き起こし, また海底に堆積することで底質の悪化などを招く．さら にアオサ類は微細藻類などと違いカ二類等の小型底生動 物の餌になりにくく，吸収された栄養塩が系外除去され ることが少ない.また処理をするにしても，アオサの有 効利用法は確立されておらず，さらに焼却場で焼却する にもアオサは含水率が $90 \%$ と高く自燃しないため, 補助 燃料を必要とし, 焼却炉に大量の砂や塩分が混入して炉 を傷めることも問題となっている（能登谷, 1999).

そのため, 干潟の環境を改善してその機能を働かせる には, 海藻の異常繁茂を制御する手法の確立が必要であ ると考えられる．しかし，グリーンタイドを構成する藻 類の特性や環境ストレスに対する耐性について調べた研

\begin{tabular}{|c|c|c|}
\hline 1 & 修(工） & 大阪市立大学大学院工学研究科都市系専攻 \\
\hline 2 正会員 & 工博 & $\begin{array}{l}\text { 大阪市立大学講師大学院工学研究科 } \\
\text { 都市系専攻 }\end{array}$ \\
\hline 3 正会員 & 農博 & $\begin{array}{l}\text { 大阪市立大学教授大学院工学研究科 } \\
\text { 都市系専攻 }\end{array}$ \\
\hline
\end{tabular}

究は少ない.そこで本研究では，まず大阪南港野鳥園に 繁茂する大型藻類の季節的な消長を知るために現地調査 を行い，またグリーンタイドを構成する海藻として報告 されているアナアオサ (Ulva pertusa), ミナミアオサ (Ulva ohnoi)， ネダシグサ (Rhizoclonium riparium) のス トレス耐性を調べ，大型藻類の異常繁茂を軽減する方法 を検討した。そして調査と実験の結果をふまえ，物質転 送が円滑に行われる干潟環境を構築するための, 現地に 適用可能なグリーンタイド抑制手法を考察した.

\section{2. 大阪南港野鳥園北池に繁茂する海藻の季節的 消長}

本研究の調査地である大阪南港野鳥園（図-1）は，施 設面積 19.3haの内に塩性湿地 $12.8 \mathrm{ha}$ を有する野鳥の飛来 地となっている．シギ・チドリなどの多くの渡り鳥が慨 場や休息の場として利用する重要な場所であり，人工干 潟でありながら環境省の「日本の重要湿地 $500 」 に も$ 選 ばれている. 年間約 10 万人以上の人々がレクリエーショ ンや自然観察の場として訪れ，市民を対象とした勉強会 や観察会も頻繁に行われており，年間来園者数は2009年 からも増加し続けている。また1999年から毎年6月から 7月にかけてボランティアによるアオサ取りが行われて

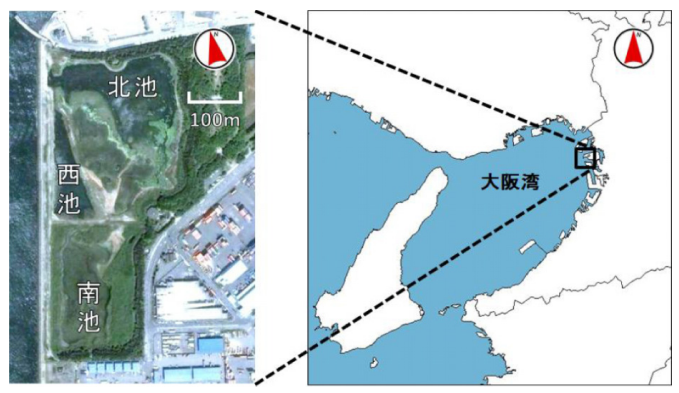

図-1 大阪南港野鳥園位置図 
おり（矢持ら，2007）, 2011年7月には環境問題に興味を 持つ外国人の参加も数名見受けられた.

しかし，大阪南港野鳥園では毎年アオサ取りが行われ ているように，海藻の大量発生が問題となっており，ま た海藻の繁茂量や種は毎年変化している。このことから 大阪南港野鳥園に繁茂する海藻の季節的消長を調べ，グ リーンタイドに関する知見を得ることを目的に調查を行 った。なお，2011年以前については神保（2007），西川 (2009)，芳村・矢持（2011）のデー夕を用いた.

\section{(1) 調查方法}

大阪南港野鳥園北池に図-2のように計 16 の調査地点 （Sts. A-P）を設け，2011年6月 15 日，8月31日，11月 2 日，2012年4月 18 日， 5 月 23 日，6月 20 日，7月 4 日， 8 月 29 日，9月 26 日， 10 月 24 日， 11 月 7 日，2013年2月 27 日に海藻の採取を行った。なお，2011年以前の海藻採取 の方法は, 本研究と同様に $0.5 \mathrm{~m} \times 0.5 \mathrm{~m}$ の立体コドラー 卜（採取面積 $0.25 \mathrm{~m}^{2}$ ）を設置し，コドラート内にある海 藻が採取されている。採取した海藻は陸上に持ち帰り, 電子天秤にて湿重量の測定，種の査定を行った。また調 查地点で採取した海藻の調查日ごとの全地点平均湿重量

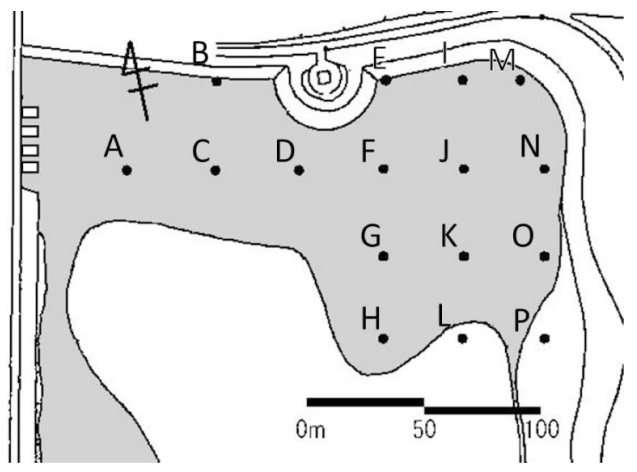

図-2 大阪南港野鳥園北池の調査地点
を求め, 北池全体の平均海藻現存量として評価した.

\section{(2) 結果と考察}

図-3に大阪南港野鳥園北池に打ける海藻の平均湿重量 の推移を示す. 調査当初は緑藻の一種であるアナアオサ （U. pertusa）がグリーンタイドの原因種として繁茂して いたが，第 1 優占種が変化し，2009年の冬季から同じ緑 藻であるミナミアオサ（U. ohnoi） の増殖が見られるよ うになり，2011年の調査では夏季の第 1 優占種がアナア オサからミナミアオサへと遷移していた。他の海藻が繁 茂している様子も観測できたが，その多くが現存量 500g-wet $/ \mathrm{m}^{2}$ 以下を示し，グリーンタイドを形成するには いたらなかった。また，2012年は，ミナミアオサやスジ アオノリ（Enteromorpha prolifera）の出現を確認するこ とはできたものの，グリーンタイドを形成するほどの大 量発生は認められなかった。

グリーンタイドを形成する海藻の種類がアナアオサか らミナミアオサに遷移した現象を考察すると，影響を及 ぼした要因として，海水温の上昇がある。ミナミアオサ は南方の温暖な海域に生息する緑藻であり，海水温上昇 によって好適増殖期間が増加している可能性がある. 第 二に，詳しくは後述するが，ストレス耐性がアナアオサ よりもミナミアオサの方が優れていることに一因すると 考えられる。この2種類の緑藻類についてストレス耐性 実験を行ったところ，ミナミアオサの方が厳しい低塩 分・干出条件下に打いて高い光合成活性を示し，このこ とからミナミアオサの方が強い干出・低塩分耐性を有し ていると判断された。干潟内外からの遊走子や配偶子の 供給と定着など，初期発生量には不明な点が残っている が，大阪南港野鳥園北池に扔ける第 1 優占種の交代には 高水温期間の増加と両種の干出・低塩分耐性の差違が関 与し, 結果的にアナアオサが駆逐されつつあると推察で きる。

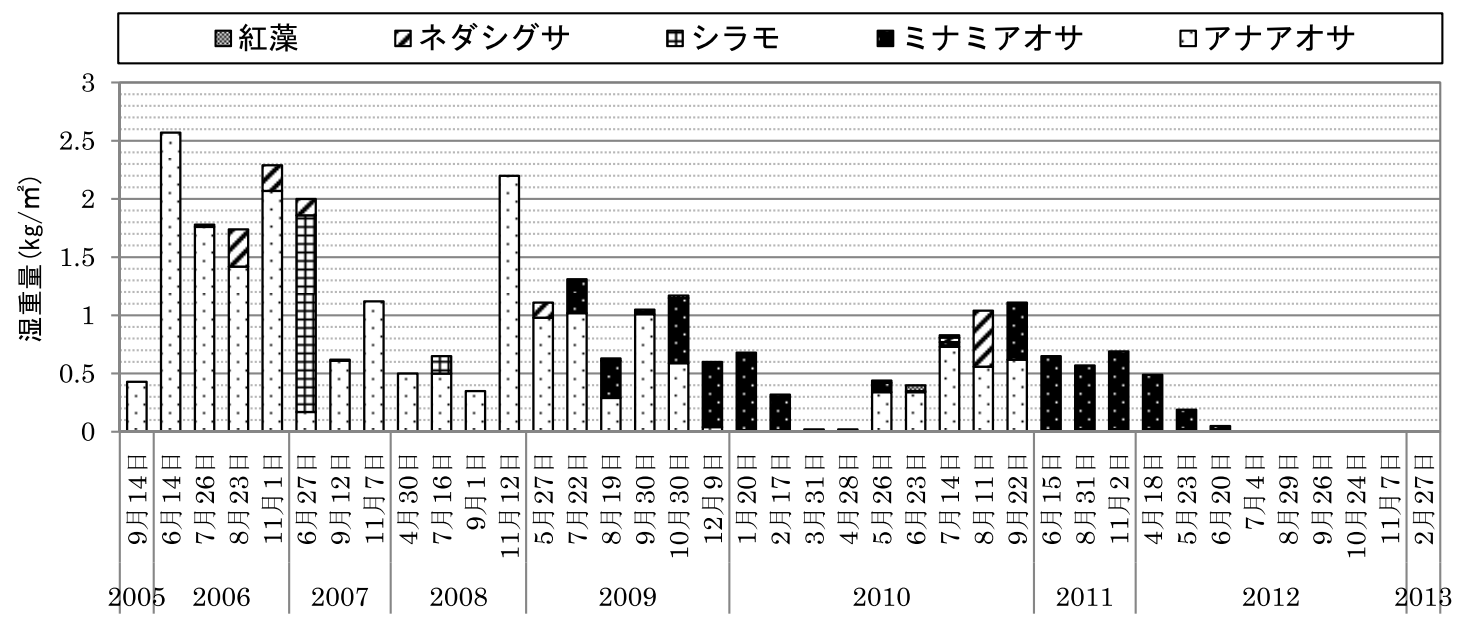

図-3 大阪南港野鳥園北池における優占海藻の現存量の推移 
また2012年に行われた調査では, グリーンタイドの発 生が確認できなかったが，この原因としては増殖期にお ける海水の低塩分化が関連すると考えられる．海藻が著 しく繁茂し始める 6,7 月頃に強い雨（1時間あたり $20 \mathrm{~mm}$ 以上 $30 \mathrm{~mm}$ 未満), 激しい雨（1時間あたり $30 \mathrm{~mm}$ 以 上 $50 \mathrm{~mm}$ 未満）の降った日が，2012年では 4 回と他の年 に比べ多く（表-1), 淡水が多く干潟内に流れ込んだ. 本 干潟では大阪湾との海水の収支が潮汐によって頻繁に行 われるため，ほほ均一な塩分分布を有しているが，閉鎖 的海域のため降雨による塩分低下の影響を受けやすい. 干出時や潮位の低い時に多量の雨が降り, 低塩分化した ことがアオサなどの海藻の増殖の妨げとなり, グリーン タイドが発生しなかったと考えられる.また2012年の夏, 大阪南港野鳥園北池でアオサの代わりに多く見られたス ジアオノリ（E. prolifera）は，基本的に淡水が支配的な 所で見られる海藻であり, 海水が支配的な大阪南港野鳥 園では大量に繁茂することは少ない。この現象からも， 大阪南港野鳥園北池でグリーンタイドが発生しなかった ことに低塩分化の影響が推測された。

\section{3. 藻類の干出・低塩分耐性実験}

グリーンタイドを形成しやすい海藻の干出や低塩分に 関するストレス耐性についての知見は少ない。そこで, アナアオサ，ミナミアオサ，ネダシグサ（R. riparium) を用いて，干出および低塩分耐性について調べ，大阪南 港野鳥園北池内で発生するグリーンタイドを抑制する手 法について検討した。

\section{（1）実験方法}

\section{a) 供試藻体の採取, 馴致}

実験には, 大阪南港野鳥園北池で採取した海藻を恒温 室の明条件下 (約 $\left.100 \mu \mathrm{mol} / \mathrm{m}^{2} / \mathrm{s}\right)$ で, 弱く通気した濾過 海水中で保存し, 毎日海水を交換しつつ, 1 週間以内に 用いた。また，実験海水は，ガラス繊維濾紙（Whatman $\mathrm{GF} / \mathrm{F}$, 孔径 $0.7 \mu \mathrm{m})$ で滤過したものを蒸留水で目的の塩 分に希釈し, 窒素 $\left(\mathrm{NaNO}_{3}\right)$, リン $\left(\mathrm{K}_{2} \mathrm{HPO}_{4}\right)$, 微量金属 混液（PIIMetal）を補強した。さらに海水は $\mathrm{pH}$ を 8.0-8.2

表-1 大阪の降水量と海藻繁茂量の関係

\begin{tabular}{ccc}
\hline 調査年 & $\begin{array}{c}\text { 6, 7月に降水量が } \\
\text { 20mm/hを上回った日数 }\end{array}$ & $\begin{array}{c}8,9 \text { 月の海藻の繁茂量 } \\
\left(\mathrm{kg} / \mathrm{m}^{2}\right)\end{array}$ \\
\hline 2006 & 0 & 1.74 \\
\hline 2007 & 1 & 0.62 \\
\hline 2008 & 2 & 0.35 \\
\hline 2009 & 0 & 0.63 \\
\hline 2010 & 2 & 1.04 \\
\hline 2011 & 0 & 0.57 \\
\hline 2012 & 4 & 0.0 \\
\hline & & (*気象庁の気象統計情報から引用)
\end{tabular}

に調整後, 小型高圧蒸気滅菌機（ヤマト科学, SP300型) を用いて $121{ }^{\circ} \mathrm{C} て ゙ 5$ 分間加熱滅菌した。海藻は付着物を

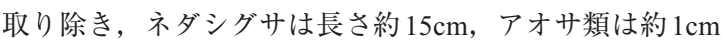
四方（ともに湿重量約 $0.1 \mathrm{~g}$ ）に細断し, 実験に先立ち, 弱光条件下 (約 $\left.1.0 \mu \mathrm{mol} / \mathrm{m}^{2} / \mathrm{s}\right)$ で実験と同じ水温と塩分 の栄養補強海水に 12 時間馴致した.

\section{b）光合成速度の測定}

海藻類へ与えるストレスとして, 温度・塩分 ·干出の $3 つ$ 環境要因を変化させ, 藻類の健康指標である光合 成が促進されるか抑制されるかを調べた。実験フロー図 を図-4に示す，塩分耐性実験では，藻体を入れた海水の 塩分を 1 時間ごとに $5 \mathrm{psu}$ ずつ低下させ，実験塩分中で 12 時間馴致した。干出耐性実験に関しては, 干出方法とし て藻体を高湿度条件（湿度 $90 \%$ 以上）の密閉容器内で, 暗条件下にて干出を再現した。低塩分・干出処理をそれ ぞれ行った後, $100 \mathrm{ml}$ フラン瓶にそれぞれ栄養補強海水 と1片の藻体を入れ, 溶存酸素計（東亜ディーケーケー 製，DO-24P型）を用いて投入直後の酸素濃度を計測し た. そして卓上人工気象器 (日本医科器械製, LH-55RDS 型, 光量子束密度: 約 $\left.100 \mu \mathrm{mol} / \mathrm{m}^{2} / \mathrm{s}\right)$ 内で 6 時間藻 体に光合成させ，その後再び海水の溶存酸素濃度を計測 した。測定後には用いた藻体の湿重量も計測し, 培養前 後の溶存酸素濃度の変化量から, 単位湿重量あたりの光 合成速度を求め, 光合成活性を評価した（式（1））

$$
P=\frac{C_{t}-C_{0}}{t} \times \frac{V}{W}
$$

$P:$ 藻体の光合成速度 $\left[\mathrm{mgO}_{2} / \mathrm{g}\right.$-wet $\left./ \mathrm{h}\right]$

$C_{t}$ : 培養後のフラン瓶内の溶存酸素濃度 $\left[\mathrm{mgO}_{2} / \mathrm{l}\right]$ $C_{0}$ : 培養前のフラン瓶内の溶存酸素濃度 $\left[\mathrm{mgO}_{2} / 1\right]$ $t:$ 培養時間 $[\mathrm{h}], V:$ フラン瓶容量 $[1]$ $W:$ 藻体の湿重量 $[\mathrm{g}$-wet $]$

\section{（2）実験結果}

ネダシグサに関する実験結果を図-5に示す． 25-35 ${ }^{\circ} \mathrm{C}$, $30 \mathrm{psu}$ の条件において, ネダシグサの光合成速度は 30 分 以内の干出で著しく低下した。このことからネダシグサ に関しては干出耐性に優れていないことが分かった。ア ナアオサ, ミナミアオサの 2 種の緑藻類に関しては, ミ ナミアオサの方がアナアオサよりも強い干出耐性を有し ており, $35^{\circ} \mathrm{C} て ゙ 6$ 時間干出処理を行っても $30 \mathrm{psu}$ では光合

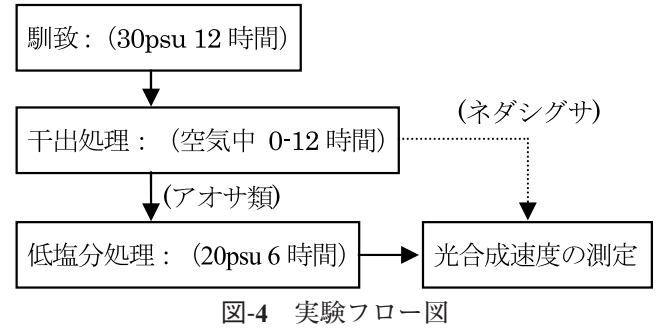


成速度の低下が見られなかった（図-6)。また両種ともに 塩分を 20psuまで下げると光合成速度が低下することか ら, この塩分では干出がなくても低塩分化の影響を受け ることが分かった。また海藻 3 種の実験結果から, 海藻 が増殖する時期に現地の海水塩分を $20 \mathrm{psu} に$ 低下させ, 干出時間を 6 時間設けることができればグリーンタイド の発生を軽減できる可能性が示唆された。

\section{4. ミナミアオサの再生実験}

現地の塩分と干出条件を変えることでグリーンタイド を軽減する可能性を述べたが, 実際に大阪南港野鳥園北 池で低塩分・干出処理を行う際, 干潟内を長期にわたっ て淡水に浸漬させることは現実的ではない．また，再び 導水管を通じて干潟内に大阪湾から海水が流入した場 合, 光合成活性の低下した藻類がグリーンタイドを形成 するほど回復する恐れがある。そこでミナミアオサにつ いて, 海水に再び戻した時にどれほど光合成活性が回復 するかを調べた。

\section{a) 実験方法}

大阪南港野鳥園で採取したミナミアオサをストレス耐 性実験と同様に細断，馴致し，干出・低塩分処理前の光 合成速度を測定した，その後，干出処理を 12 時間，低塩 分処理を 6 時間行い，处理後の光合成活性を測定した。 そして再びミナミアオサを30psuの栄養補強海水で 24 時 間（12:12 LD）培養し，回復処理後の指標とするため光 合成速度を測定した。

\section{b）実験結果}

実験開始時，干出・低塩分処理後，回復処理後の光合 成速度を図-7に示す。その結果，干出・低塩分処理によ り光合成速度が約 $1.5 \mathrm{mgO}_{2} / \mathrm{g}$-wet $/ \mathrm{h}$ に低下した後に回復処 理を行っても，24時間の海水への浸漬では実験開始時の 約 $4.0 \mathrm{mgO}_{2} / \mathrm{g}$-wet/h まで回復しないことが分かった。この ことから, 現地で低塩分・干出処理を行い，グリーンタ イド形成海藻を衰弱させた後に再び一般海水を導入して も，短期間のうちにグリーンタイドを形成するほど回復 しないことが示唆された.

\section{5. ポシェットトゲオヨコエビの耐性実験}

グリーンタイドを軽減する手段として干潟内の海水の 低塩分化や干出を行うにあたり問題となるのが，小型底 生動物への影響である.グリーンタイドを軽減すること ができたとしても，それが小型底生動物に悪影響となり， 成育の場として相応しくなくなる場合，食物連鎖が行わ れずに干潟の海水浄化機能が低下してしまう。そこで現 地の最優占小型甲殼類であるポシェットトゲオヨコエビ (Eogammarus possjeticus) の低塩分・干出耐性を調べた.

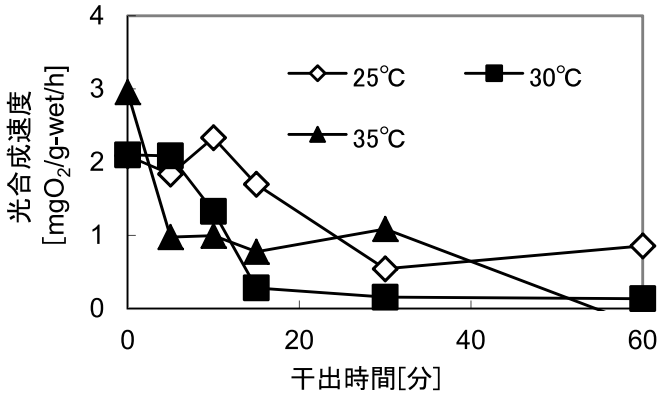

図-5 ネダシグサの光合成速度と温度・干出時間の関係

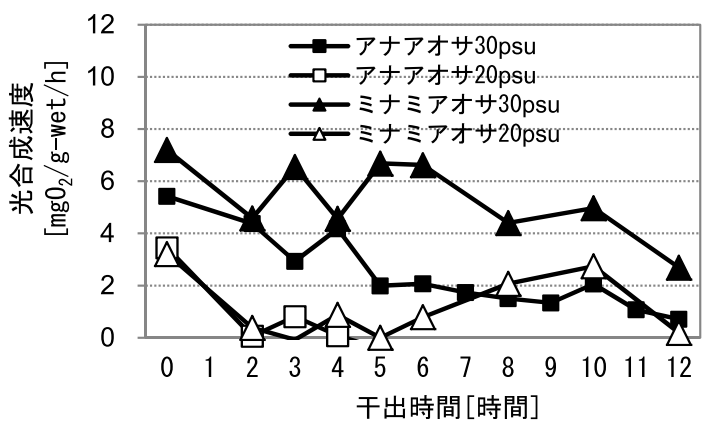

図-6 アナアオサとミナミアオサの光合成速度と塩分. 干出 時間の関係 $\left(35^{\circ} \mathrm{C}\right)$

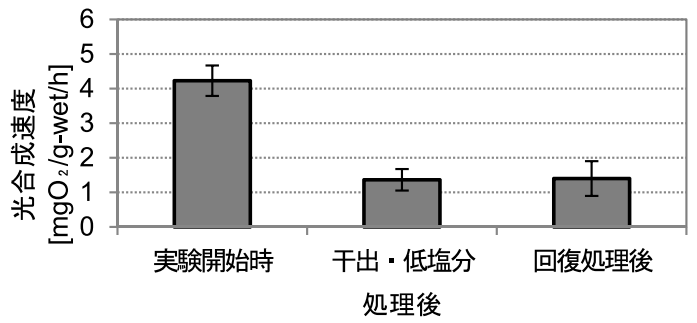

図-7 ミナミアオサの実験開始時，干出・低塩分処理後，な らびに回復処理後の光合成速度 $\left(35^{\circ} \mathrm{C}\right)$

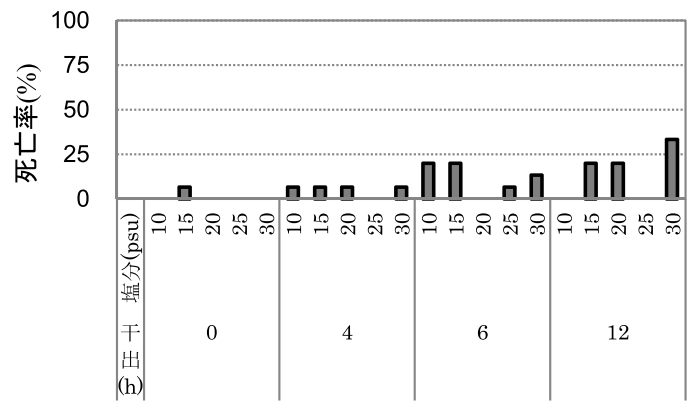

図-8 塩分・干出時間とポシェットトゲオヨコエビの死亡率 の関係 $\left(30^{\circ} \mathrm{C}\right)$

\section{a）実験方法}

大阪南港野鳥園にて採取したポシェットトゲオヨコエ ビ（体長 5-15mm）を持ち帰り，30 ${ }^{\circ} \mathrm{C}$ 実験温度で砂濾 
過海水中にて 3 時間馴致させた. そして, 藻類の実験で 行った方法と同様に湿度 $90 \%$ の空気中に0，4，6，12 時 間晒し，その後各条件に供試体を5個体ずつ用いて塩分 10-30psuの海水で24時間飼育し，生死を確認した。なお， 結果の有意差を $\chi^{2}$ 検定によって検定した.

\section{b) 実験結果}

塩分・干出時間と供試体の死亡率の関係を図-8に示 す．図から，死亡率が最も高くなった場合でも $33.3 \%$ ， 各条件において比較的高い生存率を示し，どの塩分・干 出条件間にも有意差が認められなかった。このように低 塩分や干出がポシェットトゲオヨコエビの死亡に与える 影響は小さく，本種は強い低塩分・干出ストレス耐性を 有していることが示唆された.

\section{6. 総合考察}

大阪南港野鳥園北池でグリーンタイドを形成する海藻 類は，2005年から毎年繁茂量，種類が大きく変化した. これらの現象には，高水温化や 6,7 月の多雨による海水 の低塩分化が関与する可能性が示唆された。室内実験よ り，3種のグリーンタイド原因海藻の特性が明らかにな り，干潟内の海水塩分を $20 \mathrm{psu} に し ， 干$ 出時間を 6 時間設 けることでグリーンタイド原因海藻の光合成活性が低下 し，大増殖を軽減できると考えられた。さらに，低塩 分・強干出下であっても, 小型底生動物の優占種である ポシェットトゲオヨコエビの死亡は少なかった。また, 本干潟内で見られるケフサイソガニ (Hemigrapsus penicillatus) やユビナガホンヤドカリ (Pagurus minutus) などの優占底生動物についても強い低塩分耐性を有して いることが分かっている（柳川ら，2002）。 Kuwaeら （2008）は，干潟に飛来するシギ類は干潟底泥表面のバ イオフィルムを主食とすると報告している。一見 (2004) は干潟に形成される底生微細藻類のバイオフィルムは塩 分の変動に強い耐性を有しており, 数psuから $40 \mathrm{psu}$ の広 い塩分域で増殖に悪影響がないと述べている。このため, グリーンタイド抑制環境を創出しても，食物連鎖による 栄養塩の系外除去システムに大きなダメージは少ないと 考えられる. 大阪南港野鳥園北池では, 導水管を通じて 潮位変動による大阪湾との海水交換が行われ，この導水 管を封鎖することで干出時間を調節することができる. また, 北池南側にある雨水貯留池から淡水を北池に導入 することで低塩分処理を施せる，さらに，失活した海藻 を海水に再浸漬しても短期間では大幅に光合成活性が回 復しないことから，適度の干出・低塩分処理を行ったの
ち, 再度干潟内に大阪湾から海水を導入するのが大増殖 を軽減するに打いて有効かと考えられる。これらの対策 により, 大阪南港野鳥園北池の物質転送が円滑に行われ， グリーンタイドを抑制する環境を創出できると考えられる。

\section{7. 結論}

大阪南港野鳥園北池に繁茂する海藻は量・種ともに毎 年変化し，この現象に関わる要因として高水温化，増殖 期における淡水の流入による低塩分化などの影響が考え られた。また室内実験結果から, 海藻の増殖が著しい6, 7 月に干出時間を約 6 時間設け, さらに淡水を干潟内に導 入して塩分を $20 \mathrm{psu}$ に下げることでグリーンタイドを低 減できる可能性が示唆された。さらに，再び干潟内に海 水が導入されたとしても, グリーンタイド形成海藻は 24 時間では大きく光合成活性を回復できないので，短期間 で再発する可能性の低いことがわかった。

謝辞：本研究を遂行するに際してNPO法人「南港ウェッ トランドグループ」のご支援を賜った。ここに記して感 謝の意を表します。本研究は科学研究費助成事業（基盤 研究C）都市型人工塩性湿地に打ける生物圈と環境圈間 の炭素フラックスの案態と機序解明研究により実施した.

\section{参 考 文 献}

神保幸代（2007）：都市型塩性湿地生態系に打ける物質収支と 緑藻類の分布と変遷に関する研究，大阪市立大学大学院 工学研究科修士論文, pp. 10-11

西川智貴（2009）：アオサ・ジュズモの生理特性に基づくグリ ーンタイドの抑制に関する基礎的研究-大阪南港野鳥園-, 大阪市立大学大学院工学研究科修士論文, pp. 78-79

能登谷正浩（1999）：アオサの利用と環境修復, 成山堂書店, pp. 1-171

一見和彦 (2004)：干潟域の付着珪藻の増殖生理, 日本水産学 会誌，第70卷, pp. 792-793

柳川竜一 - 矢持 進 - 中谷恵美 - 小田一紀 (2002)：大阪南港 野鳥園湿地の環境特性と生物多様性を重視した浅場環境 の造成条件, 海岸工学論文集, 第49巻, pp. 1281-1285.

矢持 進・神保幸代・武田尚大 (2007)：都市型塩性湿地生態 系における緑藻類の分布と変遷について, 海岸工学論文 集, 第 54巻, pp. 1186-1190.

芳村 碧・矢持 進 (2011) : 大阪南港野鳥園北池に捄けるグ リーンタイドの季節的変遷と原因海藻ミナミアオサの低 塩分・干出耐性に関する研究, 土木学会論文集, B2 vol,67, No.2, 2011, I_1136-I_1140.

Kuwae T., P. G. Beninger, P. Decottignnies, K. J. Mathot, D. R. Lund and R.W. Elner. (2008): Biofilm grazing in a higher vertebrate:The western sandpiper, Calidris mauri, Ecology, 89, pp. 599-606. 